\title{
EFEKTIFITAS METODE MIND MAPPING UNTUK MENINGKATKAN PRESTASI BELAJAR FISIKA PADA SISWA KELAS VIII
}

\author{
Muhammad Chomsi Imaduddin \& Unggul Haryanto Nur Utomo \\ Fakultas Psikologi \\ Universitas Ahmad Dahlan \\ Jl. Kapas No. 9 Yogyakarta \\ unggul85@yahoo.com.
}

\begin{abstract}
Abtract
This study aimed to determine the effectiveness of mind mapping method to improve the learning achievements of physics. The subjects of this study were students in grade VIII of SMP Muhammadiyah 8 Yogyakarta which have average score of physics subjects below 6.5, and have the ability to see and hear well. Data collection methods used in this study was the academic score on the physics subject of optical tools, documentation, observation and interview. This study used the experimental method of pretest-posttest with control group design and used the t-test analysis. The results of paired sample t-test analysis in experimental group obtained that mind mapping method has highly significant positive effect in enhancing achievement of physics learning $(t=-11.006, p=0.000)$. The results of the paired sample t-test analysis in control group showed that conventional method has insignificant influence on achievement enhancement of physics learning $(\mathrm{t}=-1.941, \mathrm{p}=0.070)$ and the independent sample $\mathrm{t}$-test in both group found that there are significant difference of average (mean) posttest score between the experimental group and control group $(\mathrm{t}=2.144, \mathrm{p}=$ $0.020)$. The results demonstrate mind mapping method is very effective in improving the learning achievements of physics.
\end{abstract}

Keywords: Learning Achievement, Mind Mapping Method, Physics.

\begin{abstract}
Abstrak
Penelitian ini bertujuan untuk mengetahui efektifitas metode mind mapping untuk meningkatkan prestasi belajar fisika. Subjek penelitian ini adalah siswa kelas VIII SMP Muhammadiyah 8 Yogyakarta yang memiliki nilai mata pelajaran fisika rata-rata di bawah 6,5 , memiliki kemampuan
\end{abstract}


melihat dan mendengar dengan baik. Metode pengumpulan data dengan alat ukur tes prestasi belajar fisika pada materi alat optik, dokumentasi, observasi dan wawancara. Penelitian ini menggunakan metode eksperimen dengan rancangan pretest-posttest control group design. Data dianalisis dengan menggunakan teknik analisis uji-t. Hasil analisis uji-t yaitu paired sample t-test pada kelompok eksperimen, diperoleh bahwa metode mind mapping berpengaruh positif yang sangat signifikan terhadap peningkatan prestasi belajar fisika $(\mathrm{t}=-11,006 ; \mathrm{p}=0,000)$. Hasil analisis uji-t yaitu paired sample t-test pada kelompok kontrol, diperoleh bahwa metode konvensional tidak berpengaruh positif terhadap peningkatan prestasi belajar fisika $(\mathrm{t}=-1,941 ; \mathrm{p}=0,070)$. Hasil analisis uji-t yaitu Independent sample t-test pada kelompok eksperimen dan kelompok kontrol, diperoleh bahwa ada perbedaan yang signifikan antara rata-rata (mean) hasil posttest antara kelompok eksperimen dan kelompok kontrol $(\mathrm{t}=2,144 ; \mathrm{p}=0,020)$. Hasil penelitian menunjukkan metode mind mapping sangat efektif dalam meningkatkan prestasi belajar fisika.

Kata kunci: Fisika, Metode Mind Mapping, Prestasi Belajar

\section{Pendahuluan}

Prestasi belajar merupakan hal yang tidak dapat dipisahkan dari kegiatan belajar, karena kegiatan belajar merupakan proses, sedangkan prestasi merupakan hasil dari proses belajar. Menurut Kamus Besar Bahasa Indonesia, prestasi belajar adalah penguasaan pengetahuan atau keterampilan yang dikembangkan oleh mata pelajaran yang lazimnya ditunjukkan dengan hasil tes atau angka nilai yang diberikan oleh guru (Surakhmad, 2000).

Nuh (Ratya, 2010) menjelaskan, di Indonesia masih banyak sekolah yang hampir semua siswanya tidak lulus ujian nasional. Menurut data Kementerian Pendidikan Nasional (Ratya, 2010), ada sebanyak 267 dari 16.467 sekolah yang mengikuti Ujian Nasional 2010 (UN) memiliki persentase kelulusan 0\% atau semua siswanya tidak lulus. Dari 267 sekolah itu jumlah siswa yang tidak lulus sebanyak 7.648 siswa dari total 1.522.156 siswa yang mengikuti UN. Di Provinsi Kalimantan Timur misalnya, ada 39 sekolah seluruh siswanya tidak lulus (1.158 siswa). Khusus di SMP Muhammadiyah 8 Yogyakarta, hasil ujian UN tahun pelajaran 2010, yang tidak lulus adalah 35,37\% yaitu 29 siswa dari 83 siswa, dan dari 29 siswa tersebut, yang tidak lulus dalam UN ulang sebanyak 48,28 \% yaitu 14 siswa. Delapan siswa 
diantaranya tidak lulus dalam mata pelajaran IPA.

Fisika merupakan bagian yang tidak terpisahkan dari ilmu pengetahuan alam (IPA). Setiap manusia tanpa disadari telah mengenal dan mempraktekkan ilmu pengetahuan alam (IPA) sejak dilahirkan, peralatan berteknologi canggih yang digunakan manusia untuk melangsungkan proses kehidupannya sebagian besar merupakan aplikasi dari IPA.

Menurut Santika (2009), ilmu pengetahuan alam(IPA) merupakan bagian dari ilmu pengetahuan yang berkaitan erat dengan makhluk hidup (life science) dan alam semesta (physical sciences) dan perlu dilakukan suatu eksperimen untuk penguatan secara konseptual. Menurut Sumanji (Santika, 2009), IPA dalam arti sempit merupakan disiplin ilmu yang terdiri dari physical sciences dan life science, dan ilmu fisika adalah salah satu disiplin ilmu yang masuk ke dalam kelompok physical sciences.

Petty (Syah, 2010) menjelaskan indikator-indikator prestasi belajar dikelompokkan menjadi tiga ranah, yaitu:

a. Ranah cipta (kognitif)

Mencakup pengamatan, ingatan, pemahaman, penerapan, analisis, dan sintesis (dapat menyimpulkan).

b. Ranah rasa (afektif)

Meliputi penerimaan, sambutan, apresiasi (sikap menghargai), internalisasi (pendalaman), dan karakterisasi (penghayatan).

c. Ranah karsa (psikomotorik)

Mencakup keterampilan bergerak dan bertindak serta kecakapan ekspresi verbal dan non verbal.

Hasil prestasi siswa tentu sangat dipengaruhi oleh beberapa faktor, antara lain guru. Dalam hal ini kaitannya dengan metode pembelajaran yang digunakan oleh guru dalam mengajar.

Dalam kegiatan belajar mengajar (KBM), seorang guru memiliki peranan yang sangat penting. Menurut Sudarman (2009), kehadiran guru dalam proses pembelajaran masih tetap memegang peranan penting. Oleh karena itu guru perlu memiliki keterampilan dalam memilih metode yang tepat ketika menyampaikan suatu materi kepada peserta didiknya agar menjadi lebih menarik, tidak mengalami kebosanan dan dapat menerima materi tersebut dengan mudah, yang tentu hal tersebut akan menunjang prestasi belajarnya. Dengan demikian, metode yang digunakan harus dapat melibatkan kedua belah otak peserta didiknya. Menurut Alamsyah (2009), belajar haruslah fun, melibatkan emosi, kesenangan, kreativitas dan sebagainya, dengan demikian belajar akan melibatkan belahan otak kiri dan belahan otak kanan sekaligus. 
Menurut Alamsyah (2009), ketidakseimbangan penggunaan otak kiri dan otak kanan akan menyebabkan ketidakoptimalan dalam menyerap materi. Menurut Alamsyah (2009), penggunaan otak secara alami merupakan optimalisasi kedua belah otak, bukan hanya membebankan pada salah satu belahan otak saja. Beban yang berlebihan pada belahan otak kiri akan menyebabkan seseorang merasa cepat bosan, mudah lupa, melamun, dan sebagainya. Fenomena inilah yang terjadi di SMP Muhammadiyah 8 Yogyakarta.

Berdasarkan observasi yang dilakukan penulis di kelas VIII B, VIII C dan VIII D SMP Muhammadiyah 8 Yogyakarta, terlihat saat guru menerangkan materi pelajaran fisika, ada siswa yang tidak memperhatikan, antara lain ada siswa yang tidur-tiduran, berbicara dengan teman sebelahnya bahkan di belakangnya, berbicara dengan teman sebelahnya sambil menggambar di kertas, dan ada juga yang saling berkirim surat antara meja satu dengan meja yang lain. Hal ini terjadi karena metode mengajar yang digunakan guru tidak melibatkan sisi kreatif atau belahan otak kanan siswa, sehingga materi pelajaran fisika tersebut menjadi kurang menarik untuk dipelajari bagi para siswanya dan siswapun menjadi bosan. Akibatnya siswa tersebut tidak memahami materi pelajaran yang diajarkan guru. Siswa yang tidak memahami materi pelajaran yang diajarkan guru, tentu akan menyulitkan siswa bahkan ketidakmampuan dalam menyelesaikan suatu soal. Hal tersebut tentu akan menurunkan prestasi belajarnya.

Hasil observasi tersebut dikuatkan dengan hasil wawancara yang dilakukan oleh penulis dengan beberapa siswa kelas VIII serta dengan guru fisika. Hasil wawancara yang dilakukan penulis dengan beberapa siswa kelas VIII, menurut siswa, saat guru menerangkan pelajaran fisika, mereka merasa tidak cocok dengan cara mengajar guru tersebut, akibatnya mereka merasa jenuh dan bosan di dalam kelas, pada saat itulah meraka tidak memperhatikan pelajaran, dengan melakukan aktivitas pengalihan antara lain berbicara dengan teman, menggambar, tidur-tiduran, melamun dan lain sebagainya. Oleh karena itu, mereka mengharapkan guru lebih menarik dan menyenangkan saat menyampaikan suatu materi. Hasil wawancara yang dilakukan penulis dengan guru adalah guru tersebut menyadari bahwa metode pembelajaran yang selama ini digunakan adalah salah satu penyebab siswa-siswanya tidak memperhatikan pelajaran yang diterangkannya, sehingga prestasi belajar siswa kurang optimal. Selain itu, guru tersebut menyadari bahwa metode konvensional yang biasa digunakannya, kurang melibatkan sisi kreatifitas siswa, sehingga pelajaran yang disampaikan menjadi kurang menarik bagi siswa. Hal tersebut dikuatkan dengan data nilai yang didapat, bahwa rata-rata perolehan nilai fisika kelas VIII di SMP 
Muhammadiyah 8 Yogyakarta tahun ajaran 2010/2011 yang tuntas adalah 34,51 \% yaitu 39 siswa dari 113 siswa.

Berdasarkan fenomena tersebut, alternatif solusi yang dapat dilakukan adalah mengubah metode pembelajaran menjadi lebih menarik bagi siswa yaitu metode yang dapat melibatkan kedua belahan otak. Metode yang dimaksud adalah metode mind mapping. Mind map adalah cara mencatat yang kreatif, efektif, dan secara harfiah akan memetakan pikiran-pikiran kita (Buzan, 2009). Catatan yang dibuat tersebut membentuk gagasan yang saling berkaitan, dengan topik utama di tengah dan subtopik serta perincian mejadi cabang-cabangnya. Hal tersebut dapat menjadikan siswa merasa senang dan tidak bosan dalam mengikuti pelajaran, sehingga dapat meningkatkan prestasi belajar (Wicoff, 2005).

Menurut Buzan (2009), mind map adalah cara termudah untuk menempatkan informasi ke dalam otak dan mengambil informasi ke luar dari otak. Mind map adalah cara mencatat yang kreatif, efektif, dan secara harfiah akan memetakan pikiranpikiran kita. Catatan yang dibuat tersebut membentuk gagasan yang saling berkaitan, dengan topik utama di tengah dan subtopik serta perincian menjadi cabangcabangnya. Buzan (2009), menjelaskan bahwa mind map juga merupakan peta rute hebat bagi ingatan, memungkinkan kita menyusun fakta dan pikiran sedemikian rupa sehingga cara kerja alami otak dilibatkan sejak awal. Ini berarti mengingat informasi akan lebih mudah dan lebih bisa diandalkan daripada menggunakan teknik pencatatan tradisional.

Menurut Windura (2008), mind map adalah suatu teknis grafis yang dapat menyelaraskan proses belajar dengan cara kerja alami otak. Mind map melibatkan otak kanan sehingga proses pembuatannya menyenangkan, dan mind map merupakan cara paling efektif dan efisien untuk memasukkan, menyimpan, dan mengeluarkan data dari otak kita.

Menurut Alamsyah (2009), mind mapping selaras dengan cara kerja alami otak, karena mind mapping melibatkan kedua belahan otak, seseorang mencatat dengan melibatkan simbol-simbol atau gambar-gambar yang disukainya, menggunakan warna-warna untuk percabangan-percabangan yang mengindikasikan makna tertentu dan bisa melibatkan emosi, kesenangan, kreativitas seseorang dalam membuat catatan-catatan. Menurut Septiana (2007), agar pembelajaran membekas dalam ingatan peserta didik, maka diperlukan penekanan hal-hal yang telah dipelajari selama sesi kelas itu. Gambar atau tulisan yang menarik dan berkesan dapat membantu siswa mengingat kembali hal-hal yang telah mereka lakukan dan pelajari.

Buzan (2009) menjelaskan untuk membuat mind map, bahan yang diperlukan 
adalah sebagai berikut:

1) Kertas, minimal berukuran $\mathrm{A} 4$

2) Pensil warna atau sepidol

3) Imajinasi.

4) Otak kita sendiri

Alamsyah (2009) menjelaskan setiap peta pikiran (mind map) mempunyai elemen-elemen sebagai berikut:

1) Pusat peta pikiran atau central topic, merupakan ide atau gagasan utama.

2) Cabang utama atau basic ordering ideas (BOI), cabang tingkat pertama yang langsung memancar dari pusat peta pikiran.

3) Cabang, merupakan pancaran dari cabang utama, dapat dituliskan ke segala arah.

4) Kata, menggunakan kata kunci saja.

5) Gambar, dapat menggunakan gambar-gambar yang disukainya.

6) Warna, gunakan warna-warni yang menarik dalam peta pikiran.

Langkah-langkah membuat mind map (Windura, 2008):

1) Mulai dari bagian tengah kertas kosong yang sisi panjangnya diletakkan vertikal atau horizontal

2) Menentukan central topic yang akan dibuat dengan metode mind mapping, central topic biasanya adalah judul buku atau judul bab yang dipelajari dan harus diletakkan di tengah kertas serta diusahakan berbentuk gambar.

3) Membuat basic ordering ideas (BOI) untuk central topic yang telah dipilih, gunakan warna yang berbeda pada masing-masing garis BOI. BOI biasanya adalah judul bab atau sub bab dari buku yang akan dipelajari atau bisa juga dengan menggunakan 5WH (what, where, why, who, when, dan how). Buzan (2009) menjelasakan garis BOI dibuat lebih tebal dibandingkan dengan garis cabang-cabang selanjutnya setelah cabang utama (BOI) dan seluruh garis cabang utama (BOI) harus tersambung ke pusat/central topic .

4) Melengkapi setiap BOI dengan cabang-cabang yang berisi data-data pendukung yang terkait garis cabang kedua, ketiga, dan selanjutnya lebih tipis dibandingkan garis cabang utama (BOI) dan warna garis cabang kedua, ketiga, dan selanjutnya tersebut mengikuti warna BOI nya masing-masing

5) Melengkapi setiap cabang dengan gambar, simbol, kode, daftar, grafik agar lebih menarik, lebih mudah untuk diingat dan dipahami, jika perlu lengkapi dengan garis penghubung bila ada BOI yang saling terkait satu dengan lainnya serta tuliskan kata kuncinya saja untuk setiap garis.

Alamsyah (2009) menyebutkan beberapa manfaat dari penggunaan metode mind mapping, antara lain:

a. Dapat melihat gambaran secara menyeluruh dengan jelas 
b. Dapat melihat detail tanpa kehilangan benang merahnya antar topik

c. Terdapat pengelompokkan informasi

d. Menarik perhatian mata dan tidak membosankan

e. Memudahkan berkonsentrasi

f. Proses pembuatannya menyenangkan karena melibatkan warna, gambar-gambar dan lain-lain

g. Mudah mengingatnya karena ada penanda-penanda visualnya

Windura (2008) menambahkan khusus dalam bidang pendidikan dan pembelajaran, kegunaan dan aplikasi mind map sangat banyak, antara lain untuk meringkas, mengkaji ulang (review), mencatat, mengajar, bedah buku, presentasi, penelitian dan manajemen waktu (time management).

Dalam proses kegiatan belajar mengajar (KBM), penggunaan metode mind mapping melibatkan kedua belahan otak, sehingga melibatkan sistem limbik (melibatkan emosi positif), yaitu dapat membuat siswa senang saat belajar karena melibatkan belahan otak kanan. Menurut Rose dan Nicholl (2002), rasa senang merupakan salah satu elemen penting dalam proses belajar, apabila seseorang melibatkan sistem limbik (melibatkan emosi positif) dalam proses belajar atau mengajar, maka seseorang itu akan menggunakan kekuatan besar yang membuat proses belajar jauh lebih efektif dan dapat menciptakan memori yang kuat, siswa dapat lebih mudah memasukkan, menyimpan, dan mengeluarkan data dari otaknya, sehingga prestasi belajar yang diraih dapat lebih optimal.

Penggunaan metode mind mapping dalam proses belajar mengajar khususnya untuk mata pelajaran fisika, diharapkan dapat meningkatkan kualitas pendidikan dan pengajaran serta dapat menjadikan siswa merasa senang, tidak bosan dalam mengikuti pelajaran, lebih mudah dalammenerima, memahami, mengingat dan memanggil kembali informasi yang pernah didapatkannya ketika dibutuhkan, misalnya ketika dibutuhkan untuk menyelesaikan soal mata pelajaran. Keberhasilan siswa dalam menyelesaikan soal, tentu akan membuat siswa tersebut mendapatkan prestasi yang baik.

Berdasarkan uraian di atas, muncul pertanyaan apakah mengajar dengan metode mind mapping dapat meningkatkan prestasi belajar? Oleh karena itu, penulis tertarik untuk melakukan penelitian efektifitas metode mind mapping untuk meningkatkan prestasi belajar fisika.

\section{Metode Penelitian}

Subjek dalam penelitian ini berjumlah 34 siswa yang berasal dari 17 siswa kelas VIII C dan 17 siswa kelas VIII D SMP Muhammadiyah 8 Yogyakarta. Siswa 
kelas VIII C yang berjumlah 17 dijadikan sebagai kelompok eksperimen dan siswa kelas VIII D yang berjumlah 17 dijadikan sebagai kelompok kontrolnya.

Dalam penelitian ini, pemilihan atau penetapan subjek penelitian dilakukan tanpa melakukan randomisasi (non-randomized), namun dipilih berdasarkan karakteristikkarakteristik tertentu yang telah ditetapkan, yaitu:

a. Memiliki nilai rata-rata di bawah 6,5 untuk mata pelajaran fisika

b. Memiliki kemampuan melihat dan mendengar dengan baik

Pengumpulan data dalam penelitian ini menggunakan alat ukur tes prestasi belajar fisika pada materi alat optik yang dibuat oleh guru, dokumentasi, observasi dan wawancara.

Alat ukur prestasi belajar dalam penelitian ini berupa soal fisika pada materi alat optik yang terdiri dari 12 soal dengan bentuk soal menjodohkan yang dibuat oleh guru dengan mengacu pada tujuan kegiatan belajar mengajar (KBM) dan soal tes prestasi belajar fisika ujian akhir semester (UAS) tentang materi alat optik. Alat ukur prestasi belajar tersebut awalnya berjumlah 20 soal yang kemudian diuji cobakan kepada subjek uji coba yaitu siswa kelas VIII A dan B di sekolah yang sama dan sudah mendapatkan materi alat optik serta yang sesuai dengan karakteristik subjek penelitian. Hasil dari uji coba tersebut kemudian dianalisis item berdasarkan indeks tarafkesukaran soal (p) dan indeks daya pembeda soal $\left(\mathrm{DP} / \mathrm{r}_{\mathrm{it}}\right)$ yang telah ditetapkan dengan bantuan microsoft office excel. Hasilnya terdapat delapan soal yang gugur, dan 12 soal lainnya lolos, 12 soal tersebut kemudian dihitung reliabilitasnya serta selanjutnya digunakan dalam penelitian ini.

Pengujian reliabilitas menggunakan metode belah dua (split-half method) dengan teknik ganjil-genap (odd-even) dengan bantuan SPSS 16.00 for Windows. Dari hasil perhitungan tersebut didapatkan hasil koefisien korelasi antara skor ganjil dan genap sebesar 0,$648 ; p=0,000(p<0,01)$, artinya korelasi antar belahan sangat signifikan, kemudian untuk menentukan koefisien reliabilitas dilanjutkan proses perhitungan dengan rumus Spearman-Brown dan didapatkan koefisien reliabilitas sebesar 0,786 , hal ini berarti soal fisika pada materi alat optik yang akan digunakan dalam penelitian ini memiliki reliabilitas yang cukup memadai.

Dokumentasi pada penelitian ini menggunakan dokumen atau catatan yang diperoleh dari sekolah dan guru untuk mengungkapkan nilai atau hasil belajar siswa. Observasi dilakukan oleh penulis saat penelitian berlangsung, untuk mengetahui perilaku atau kondisi tertentu dari subjek penelitian pada saat itu, yang hasilnya dapat dibandingkan dengan hasil observasi sebelum penelitian berlangsung. Wawancara dilakukan pada guru fisika dan beberapa subjek penelitian melalui setelah penelitian 
selesai.

Metode yang digunakan dalam penelitian ini adalah metode eksperimen, dan rancangan yang digunakan pada penelitian ini adalah pretest-posttest control group design.

Dalam penelitian ini, salah satu dari dua kelas yang terpilih menjadi sampel penelitian, dijadikan kelompok eksperimen yaitu diberi perlakuan berupa penggunaan metode mind mapping dalam proses kegiatan belajar mengajar (KBM) pelajaran fisika, sedangkan kelas lainnya dijadikan kelompok kontrol yaitu tanpa diberikan perlakuan (menggunakan metode konvensional) dalam proses kegiatan belajar mengajar (KBM) pelajaran fisika.

Sebelum guru menerangkan materi mata pelajaran fisika pada pokok bahasan alat optik, terlebih dahulu dilakukan pengukuran awal (pre test) terhadap kedua kelompok tersebut, yaitu berupa soal fisika tentang alat optik. Pada kelompok eksperimen, sebelum diberi pre test, kelompok eksperimen dan guru fisika terlebih dahulu diberi pelatihan tentang cara membuat mind map yang dilakukan sebanyak tiga kali pertemuan. Setelah dilakukan pengukuran awal pada kelompok eksperimen dan kontrol, kemudian untuk kelompok eksperimen diberi perlakuan berupa penggunaan metode mind mapping dalam proses kegiatan belajar mengajar (KBM) pelajaran fisika, yaitu guru menggunakan metode mind mapping saat menyampaikan materi tentang alat optik, sedangkan untuk kelompok kontrol menggunakan metode konvensional. Penyampaian materi alat optik pada kedua kelompok, masing-masing dilakukan sebanyak tiga kali pertemuan. Setelah guru selesai menyampaikan materi tentang alat optik, kemudian dilakukan pengukuran akhir (post test) pada kedua kelompok yaitu dengan menggunakan soal pre test.

Metode yang digunakan untuk menganalisis data dalam penelitian ini adalah metode statistik parametrik. Teknik analisis yang digunakan dalam penelitian ini adalah uji-t yaitu paired sample t-test dan independent sample t-test. Paired sample ttest digunakan untuk menguji perbedaan rata-rata (mean) antara hasil pre test dan post test pada masing-masing kelompok (kelompok eksperimen dan kelompok kontrol). Independent sample t-test digunakan untuk menguji perbedaan rata-rata (mean) hasil post test antara kelompok eksperimen dan kelompok kontrol.

\section{Hasil dan Pembahasan}

Hasil analisis uji-t yaitu paired sample t-test pada kelompok eksperimen, diperoleh bahwa metode mind mapping berpengaruh positif terhadap peningkatan 
prestasi belajar fisika. Hasil analisis uji-t diperoleh nilai $t=-11,006$ dengan $p=0,000$ $(\mathrm{p}<0,01)$, artinya sangat signifikan.

Hasil analisis uji-t yaitu paired sample t-test pada kelompok kontrol, diperoleh bahwa metode konvensional tidak berpengaruh positif terhadap peningkatan prestasi belajar fisika. Hasil analisis uji-t diperoleh nilai $t=-1,941$ dengan $p=0,070(p>0,05)$, artinya tidak signifikan.

Hasil analisis uji-t yaitu Independent sample t-test pada kelompok eksperimen dan kelompok kontrol, diperoleh bahwa ada perbedaan rata-rata (mean) hasil post test antara kelompok eksperimen dan kelompok kontrol. Hasil analisis uji-t diperoleh nilai $\mathrm{t}=2,144$ dengan $\mathrm{p}=0,020(\mathrm{p}<0,05)$, artinya signifikan. Hasil nilai rata-rata (mean) post test pada kelompok eksperimen menunjukkan nilai $\mathrm{M}=7,55$ dan pada kelompok kontrol menunjukkan nilai $\mathrm{M}=6,62$.

Dari hasil analisis data dengan menggunakan teknik uji-t yaitu paired sample t-test telah membuktikan bahwa prestasi belajar fisika pada kelompok yang diberikan perlakuan berupa penggunaan metode mind mapping dalam proses kegiatan belajar mengajar(KBM) (kelompok eksperimen) lebih tinggi dibandingkan dengan kelompok yang menggunakan metode konvensional dalam proses KBM (kelompok kontrol). Artinya penggunaan metode mind mapping dalam proses KBM pelajaran fisika lebih efektif dibandingkan dengan metode konvensional dalam peningkatan prestasi belajar fisika. Kesimpulan tersebut dikuatkan dengan hasil analisis data dengan teknik uji-t independent sample $t$-test, diperoleh hasil bahwa nilai $\mathrm{t}=2,144$ dengan $\mathrm{p}=$ $0,020(\mathrm{p}<0,05)$, artinya ada perbedaan prestasi belajar fisika yang signifikan antara kelompok eksperimen dan kelompok kontrol dengan nilai rata-rata (mean) post test pada kelompok eksperimen $(\mathrm{M}=7,55)$ lebih tinggi dibandingkan dengan kelompok kontrol $(M=6,62)$. Hasil tersebut juga dikuatkan lagi dengan hasil tes ulangan fisika pada kelompok eksperimen sebelum diadakan penelitian, dari tiga kali tes ulangan fisika yang telah dilakukan pada kelompok eksperimen, rata-rata siswa mendapatkan hasil di bawah 6,5, sedangkan hasil tes ulangan fisika setelah menggunakan metode mind mapping dalam proses KBM fisika pada materi alat optik, rata-rata siswa mendapatkan nilai di atas 6,67.

Peningkatan hasil tersebut diakui oleh guru fisika, hasil wawancara yang dilakukan dengan guru yaitu, guru mengakui adanya peningkatan nilai yang cukup bagus saat sebelum mengajar menggunakan metode mind mapping dengan setelah menggunakan metode mind mapping. Menurut guru, hal tersebut terjadi karena saat mengajar menggunakan metode mind mapping, secara keseluruhan respon anak-anak jauh lebih baik dari pada biasanya, hampir seluruhnya mereka 
memperhatikannya, mereka terlihat lebih senang, sehingga mereka lebih paham. Hasil tersebut dikuatkan dengan hasil observasi yang dilakukan oleh penulis pada saat penelitian berlangsung, bahwa pada saat guru menerangkan menggunakan metode mind mapping, secara keseluruhan mereka memperhatikan. Hasil wawancara yang dilakukan dengan guru, sesuai dengan hasil wawancara yang dilakukan dengan beberapa siswa kelompok eksperimen, yaitu siswa merasa senang, tidak bosan dan menarik saat guru mengajar dengan menggunakan metode mind mapping, karena terdapat warna, simbol-simbol dan kata-katanya singkat, serta diperintah untuk membuat mind map, sehingga mereka lebih mudah memahami, menghafal, dan mengingatnya.

Perasaan senang yang timbul pada diri siswa tersebut, merupakan emosi positif yang diatur oleh sistem limbik. Menurut Rose dan Nicholl (2002), sistem limbik berfungsi untuk mengendalikan emosi, diantaranya mengontrol rasa senang yang merupakan salah satu elemen penting dalam proses belajar karena melibatkan emosi positif. Rose dan Nicholl (2002) menjelaskan bahwa para peneliti mencatat ketika emosi positif dalam keadaan terbangkitkan, zat-zat keceriaan yang disebut endorfin terbentuk, hal ini meningkatkan aliran neurontransmiter (pelumas) yang disebut asetilkolin, proses tersebut memungkinkan terjadinya sambungan antar sel otak, sehingga otak dapat bekerja dengan sendirinya dan berfungsi lebih efisien, maka terdapat landasan ilmiah untuk menggunakan seni, drama, warna, emosi bahkan permainan sebagai alat dan sarana pendidikan.

Menurut Rose dan Nicholl (2002), jika seseorang melibatkan sistem limbik (emosi positif) dalam proses belajar atau mengajar, maka seseorang itu akan menggunakan kekuatan besar yang membuat proses belajar jauh lebih efektif dan dapat menciptakan memori yang kuat, oleh karena itu, para pendidik dihimbau untuk melibatkan emosi ketika mengajar di dalam kelas sehingga setiap siswa menggunakan lebih banyak potensi yang dimilikinya.

Menurut Alamsyah (2009), belajar haruslah fun, melibatkan emosi, kesenangan, kreativitas dan sebagainya, dengan demikian belajar akan melibatkan belahan otak kiri dan belahan otak kanan sekaligus. Ketidakseimbangan penggunaan otak kiri dan otak kanan akan menyebabkan ketidakoptimalan dalam menyerap materi. Penggunaan otak secara alami merupakan optimalisasi kedua belah otak, bukan hanya membebankan pada salah satu belahan otak saja. Beban yang berlebihan pada belahan otak kiri akan menyebabkan seseorang merasa cepat bosan, mudah lupa, melamun, dan sebagainya. Cara belajar seseorang jika sesuai dengan cara kerja alami otak, maka akan lebih mudah dalam menerima, memahami, mengingat dan memanggil kembali informasi yang pernah didapatkannya ketika dibutuhkan. 
Efektifnya penggunaan metode mind mapping dalam proses KBM untuk meningkatkan prestasi belajar fisika selaras dengan teori dari beberapa ahli dan hasil penelitian sebelumnya. Menurut Windura (2008) dan Menurut Alamsyah (2009), mind map adalah suatu teknis grafis yang dapat menyelaraskan proses belajar dengan cara kerja alami otak. Mind map melibatkan kedua belahan otak (kiri dan kanan), sehingga proses pembuatannya menyenangkan karena melibatkan otak kanan, dan mind map merupakan cara paling efektif dan efisien untuk memasukkan, menyimpan, dan mengeluarkan data dari otak kita. Belajar dan mengajar menggunakan metode mind mapping melibatkan emosi, kesenangan, kreativitas seseorang dalam membuat catatan-catatan. Hasil penelitian Ornstein (Rose dan Nicholl, 2002) menunjukkan bahwa proses berpikir adalah kombinasi kompleks kata, gambar, skenario, warna dan suara, dengan demikian, proses menyajikan dan menangkap isi pelajaran petapeta pikiran (mind map) merupakan oprasi alamiah dalam berpikir. Berdasarkan hasil penelitian Budiman (2008), dengan judul penerapan teknik peta pikiran untuk meningkatkan pemahaman siswa pada mata pelajaran ilmu pengetahuan sosial kelas VC SD Santa Ursula Bumi Serpong Damai (BSD) menunjukkan bahwa penerapan teknik peta pikiran dapat meningkatkan penguasaan kompetensi dasar siswa dengan adanya hasil belajar yang lebih baik

Dalam penelitian ini, penggunaan metode mind mapping dalam proses KBM fisika mendorong siswa untuk terbiasa membaca sekilas secara keseluruhan kemudian mencari hal-hal yang penting dengan menuliskan kata kunci dari teks yang dibacanya, siswa mulai terbiasa melengkapinya dengan gambar atau simbol untuk memudahkan pemahaman dari benda atau keadaan-keadaan yang nyata. Menurut DePorter, Reardon dan Nourie (2005), kegiatan siswa membuat mind map dari buku yang baru dibacanya, akan meningkatkan pemahaman, ingatan, dan juga mind map tersebut dapat digunakan kelak dalam belajar menghadapi ujian, serta siswa menjadi lebih aktif dan kreatif dalam proses KBM pelajaran fisika sehingga hipotesis diterima.

\section{Simpulan}

Simpulan dari penelitian ini adalah metode mind mapping berpengaruh positif terhadap peningkatan prestasi belajar fisika dibandingkan dengan metode konvensional, sehingga ada perbedaan prestasi belajar fisika yang signifikan antara kelompok eksperimen dan kelompok kontrol, prestasi belajar fisika kelompok eksperimen lebih tinggi dibandingkan kelompok kontrol. 


\section{Daftar Pustaka}

Alamsyah, M. (2009). Kiat Jitu Meningkatkan Prestasi Belajar dengan Mind Mapping. Yogyakarta: Mitra Pelajar.

Budiman, P. (2008). Penerapan Teknik Peta Pikiran untuk Meningkatkan Pemahaman Siswa pada Mata Pelajaran Ilmu Pengetahuan Sosial Kelas V C SD Santa Ursula BSD. Jurnal Psiko-Edukasi. Volume 6: 34-51.

Buzan, T. (2009). Buku Pintar Mind Map. Jakarta: PT. Gramedia Pustaka Utama.

Deporter, B. Reardon, M. \& Nourie, S.S. (2005). Quantum Teaching. Bandung: Kaifa.

Ratya, P.M. (2010). Mendiknas: 267 Sekolah Siswanya Tak Lulus 100 Persen. http://www.detiknews.com/read/2010/04/27/204259/1346669/10/ mendiknas-267-sekolah-siswanya-tak-lulus-100-persen. 27 Oktober 2010 .

Rose, C. \& Nicholl, M.J. (2002). Accelerated Learning. Bandung: Yayasan Nuansa Cendekia.

Santika, N. (2009). Seni Mengajarkan IPA Berbasis Kecerdasan Majemuk. Bogor: CV Regina.

Septiana, N. (2007). Media Belajar dari Sudut Pandang Psikologi Pembelajaran. Jurnal Pendidikan Inovatif. Volume 3: 11-15.

Slameto. (2010). Belajar dan Faktor-faktor yang Mempengaruhinya. Jakarta: Rineka Cipta.

Sudarman. (2009). Peningkatan Pemahaman dan Daya Ingat Siswa Melalui Strategi Preview, Question, Read, Reflect, Recite, dan Review (PQ4R). Jurnal Pendidikan Inovatif. Jilid 4. Nomor 2: 67-72.

Sunandar. (2008). Pengaruh Model Pembelajaran Number Head Together (NHT) terhadap Minat dan Hasil Belajar Matematika Siswa Kelas V SDN di Kecamatan Banyumanik Kota Semarang Tahun Ajaran 2008/2009. Jurnal Varia Pendidikan. Volume 20: 164-172.

Surakhmad, W. (2000). Psikologi Pemuda Sebuah Pengantar dalam Perkembangan Pribadi dan Interaksi. Bandung: PT Remaja Rosdakarya.

Syah, M. (2010). Psikologi Pendidikan. Bandung: PT Remaja Rosdakarya. 
Wicoff, J. (2005). Menjadi Super Kreatif Melalui Metode Pemetaan Pikiran. Bandung: Kaifa.

Windura, S. (2008). Be An Absolute Genius. Jakarta: Elex Media Komputindo. 